Y YEARBOOK' of ANTITRUST and REGULATORY STUDIES www.yars.wz.uw.edu.pl
Peer-reviewed scientific periodical, focusing on legal and economic issues of antitrust and regulation. Creative Commons Attribution-No Derivative Works 3.0 Poland License.

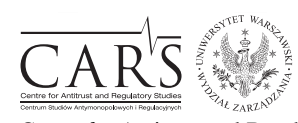

Centre for Antitrust and Regulatory Studies, University of Warsaw, Faculty of Management www.cars.wz.uw.edu.pl

\title{
Empowering the 'Unempowerable'. Behavioural Insights into Informing Consumers about Internet Access Services in the European Union under Regulation 2015/2120
}

\author{
by
}

Andrzej Nałęcz

\section{CONTENTS}

I. Introduction

II. Behavioural insights into the ideal of consumer empowerment

III. Empowering sophisticated consumers through the law - disclosure obligations under Article 4 (1) of Regulation 2015/2120

1. Introduction to disclosure obligations under Article 4 (1)

2. Information on the impact of traffic management measures

3. Information on the influence of volume limitations and quality of service parameters

4. Information on the impact of specialised services

5. Information on download and upload speeds

6. Information on the remedies available to consumers

7. Publishing information specified in Article 4 (1)

IV. Empowering unsophisticated consumers through the insights of behavioural economics - labelling internet access services

V. Conclusions

\section{Abstract}

The European consumer policy relies on the ideal of consumer empowerment, which involves providing all consumers with detailed information on the goods on offer. This policy also applies to the electronic communications sector, and

* Dr Andrzej Nałęcz, Assistant Professor, Faculty of Management, University of Warsaw; e-mail: ANalecz@wz.uw.edu.pl. Article received: 30 May 2018; accepted: 2 November 2018. 
empowering consumers who are the end-users of internet access services. The author reviews behavioural law and economics literature that pertains to consumer empowerment and applies the resulting insights to interpret Article 4 (1) of Regulation 2015/2120 laying down measures concerning open internet access in a way that would truly empower the sophisticated consumers. The author also proposes advising or obliging the providers of internet access services to label those services to provide even the unsophisticated consumers with meaningful and understandable information.

\section{Resumé}

La politique européenne des consommateurs repose sur l'idéal de l'autonomisation des consommateurs (consumer empowerment), qui consiste à fournir à tous les consommateurs des informations détaillées sur les produits proposés. Cette politique s'applique également au secteur des communications électroniques et habilite les consommateurs qui sont les utilisateurs finaux des services d'accès à Internet. Lauteur passe en revue la littérature sur les analyses économiques du droit relative à l'autonomisation des consommateurs et applique les idées qui en résultent pour interpréter l'article 4, paragraphe 1, du règlement 2015/2120 établissant des mesures relatives à l'accès ouvert à l'internet pour le bénéfice des consommateurs sophistiqués. L'auteur propose également de conseiller ou d'obliger les fournisseurs de services d'accès Internet à étiqueter ces services afin de fournir aux consommateurs moins sophistiqués des informations utiles et compréhensibles.

Key words: consumer empowerment; sophisticated consumers; unsophisticated consumers; internet access services; labelling contracts; open internet.

JEL: K23

\section{Introduction}

The main overall objective of the EU Consumer Policy Strategy is to empower consumers, specifically through choice, information and awareness of consumer rights and means of redress. The EU also aims to integrate consumer interests into key sectoral policies. In the article I focus on the issue of providing all consumers in the EU - both the sophisticated and the unsophisticated ones - with relevant and meaningful information pertaining to internet access services. Using insights from behavioural law and economics literature I analyse the concept of consumer empowerment and apply the resulting conclusions to, firstly, interpret Article 4 (1) of EU Regulation 
$2015 / 2120^{1}$, and secondly, to formulate policy proposals. I specify in detail the obligations of internet access providers under Article 4 (1) of Regulation $2015 / 2120$, serving to truly empower the sophisticated consumers. I also propose the issuing by national regulatory authorities of guidelines advising internet access providers to use a universal labelling system to empower also the unsophisticated consumers, by providing them with basic, understandable information on the real-world functionality of internet access services. In order to update the ideal of consumer empowerment, by dividing consumers into sophisticated and unsophisticated ones, I intentionally depart from the concept of the average consumer as formulated in the judgments of the Court of Justice of the European Union.

While the article relies to some extent on data from the Polish internet access market, the conclusions will be applicable in any EU Member State enforcing Regulation 2015/2120.

\section{Behavioural insights into the ideal of consumer empowerment}

The extent to which European consumer law relies on the ideal of consumer empowerment is deeply rooted in information economics, which concentrates on reducing the information asymmetry between sellers and buyers (Lissowska 2010, 59-60). While the concept of the average consumer, formulated by the Court of Justice in C-210/96 Gut Springenheide, does not lie at the core of European consumer law as such, it seems to unduly influence the legislation pertaining to consumer empowerment and its application. In Gut Springenheide, the Court described an average consumer as one who is 'reasonably well-informed and reasonably observant and circumspect'. ${ }^{2}$ While the Court recently showed some signs of "pushing forward interpretations rendered in prior case law' (Schebesta and Purnhagen 2016), specifically in C-195/14 Teekanne, ${ }^{3}$ the concept of the 'reasonably well-informed' consumer still influences consumer policy. However, in reality consumers are not

1 Regulation (EU) 2015/2120 of the European Parliament and of the Council of 25 November 2015 laying down measures concerning open internet access and amending Directive 2002/22/ EC on universal service and users' rights relating to electronic communications networks and services and Regulation (EU) No 531/2012 on roaming on public mobile communications networks within the Union. ELI: http://data.europa.eu/eli/reg/2015/2120/oj.

2 CJ judgment of 16.07.1998, case C-210/96 Gut Springenheide and Rudolf Tusky v. Oberkreisdirektor des Kreises Steinfurt, ECLI:EU:C:1998:369.

3 CJ judgment of 04.06.2015, case C-195/14 Bundesverband der Verbraucherzentralen und Verbraucherverbände - Verbraucherzentrale Bundesverband e.V. v Teekanne GmbH \& Co. KG, ECLI:EU:C:2015:361. 
a uniform group. Already in the 1970s, Geistfeld, Sproles and Badenhop observed that consumers may be divided into two groups - the unsophisticated and the sophisticated. An unsophisticated consumer is one who uses only easily accessible and superficial measures to determine the extent to which a product possess high level characteristics (that is, the most abstract and general characteristics of a product). Such consumers are not interested in the lower level product characteristics. A sophisticated consumer is one who looks at more objective information to estimate high level product characteristics, which includes acquiring information on and analyzing its more detailed and measurable lower level characteristics (Geistfeld, Sproles and Badenhop 1977). Consequently, the practical viability of the policy of uniformly empowering all consumers by providing detailed information on goods through disclosure obligations, specifically in form contracts, is presently questioned by many scholars, especially those in the field of behavioural law and economics. They generally observe that 'Providing information to consumers without paying attention to the format, quantity, and effectiveness of the disclosure can be inefficient or have adverse effects' (Faure and Luth 2011, 346) and that 'The ideal of the consumer prudently deciding on the basis of complete information comes with costs that are prohibitively high' (Engel and Stark 2015, 108). The behavioural positions are reviewed below.

It is unrealistic to expect all consumers to read the entire contract with all its terms (Ayres and Schwartz 2014, 552). The common assumption that consumers do not read standard form contracts is often based on anecdotal evidence (Hillman and Rachlinski 2002, 436; Ben-Shahar 2009, 2; Bar-Gill and Ben-Shahar 2012, 117). However, this view is also strongly supported by concrete studies conducted in the last ten years, which show that, firstly, many consumers do not even attempt to read a standard form contract, and, secondly, almost all of those who read it, do so perfunctorily, spending only a token amount of time on the activity (Stark and Choplin 2009, 677-688; ${ }^{4}$ Eigen 2012;5 Bakos, Marotta-Wurgler and Trossen 2013; ${ }^{6}$ Obar and Oeldorf-

${ }^{4}$ Of the 91 undergraduate students who participated in the study, $95.6 \%$ signed a consent form they were presented with, styled after a form contract, even though it contained extremely disadvantageous, fraudulent terms. Only four participants read enough of the consent form to spot its fraudulent content and refused to sign it. Of the 87 participants who signed the form, $86.2 \%$ did not even look at it and $10.3 \%$ looked so briefly that they could not have read it - their average reading time was 2 seconds (Stark and Choplin 2009, 681).

5 Of the 1003 subjects who had the opportunity to read the contract supplied in the study, $28.9 \%$ did not read it at all. The mean time spent reading by the remaining participants, excluding three outliers, was just 54.1 seconds (Eigen 2012).

${ }^{6}$ Based on their study, the authors estimate the fraction of retail software shoppers who access End User Licence Agreements at between $0.05 \%$ and $0.22 \%$ (Bakos, Marotta-Wurgler and Trossen 2013, 35). 
Hirsch 2016). ${ }^{7}$ On the other hand, some scholars claim their surveys show that in fact more people read contracts than is usually assumed - if not at the time of contracting, then at least after the fact (Becher and Unger-Aviram 2010). However, these surveys come with many limitations, ${ }^{8}$ as respectively does a survey carried out for the European Commission in 2010, which also indicated a higher percentage of consumers reading contracts than real-world studies show (EC 2011). ${ }^{9}$ There appears to be a notable difference between results gained from surveys, like those of the EC, and Becher and UngerAviram, and from an analysis of people's actual behaviour, like that of Stark and Choplin, Eigen, Bakos, Marotta-Wurgler and Trossen or Obar and Oeldorf-Hirsch. One is led to speculate that while consumers realise they should read standard form contracts, and therefore tend to claim that they do it when queried about a hypothetical situation, they usually act differently in the real world, when faced with the practical transaction costs and discomfort related to actually reading contracts. This apparent paradox has been noted in the literature - people may not be willing to labour to acquire information even when they know they need it (Ben-Shahar and Schneider 2011, 710). As Korobkin put it, 'The problem that buyers face of choosing among product alternatives $(. .$.$) can be reframed as a problem of balancing the desire to$ make accurate choices with the mutually exclusive desire to minimize effort' (Korobkin 2003, 1222).

The idea to provide the consumer with important information in the contract is not invalid in itself. The problem is the amount of information provided, and the way it is presented. Stark and Choplin very appropriately describe it as userunfriendly (Stark and Choplin 2009, 655-656). Subjecting the consumer to more information than she can process leads to an information overload (Lissowska 2010, 61). This overload is caused by an overabundance of both the contract terms themselves and of the characteristics of the product on offer. Firstly, for a person without technical and legal expertise, 'distinguishing between relevant

$774 \%$ of the participants of the authors' study skipped reading the provided Privacy Policy altogether. Those participants who did read the policy, which measured 7977 words, on average spent only 73 seconds doing so, while it is estimated an average person can read 250-280 words per minute (Obar and Oeldorf-Hirsch 2016, 2, 11, 15).

8 The authors themselves realise the limitations of their research - they carried out a study among university students, including law school students, pursuing bachelor's and master's degrees. The authors admit that such a sample population is not representative of the general population. Specifically, the students' responses were probably shaped by their skills, education and the perceived expectations of their professors conducting the study (Becher and UngerAviram 2010, supra notes 62-63, at 225-226).

9 According to the survey, $31 \%$ of consumers carefully and completely read their most recent service contract (e.g. electricity, bank, telephone), and $42 \%$ of Internet shoppers did so $($ EC 2011, 10). 
and irrelevant contract terms is a very demanding task' (Becher 2007, 174). Consumers 'do not even know what information they should be looking for or whether they need to be looking for information in the first place' (Stark and Choplin 2009, 659-660), and 'Even when buyers do notice a specific contract term, they will not necessarily be able to evaluate its salience' (Korobkin 2003, 1234). Secondly, the number of product attributes buyers are likely to consider when making decisions is perhaps as low as five (Korobkin 2003, 1227). The more information consumers are presented with, the simpler their choice strategies become, resulting in sub-optimal decisions (Korobkin 2003, 1226-1227;10 Armstrong 2008, 131). Some consumers may even resolve a complicated choice situation by making a random move (Engel and Stark 2015, 113). ${ }^{11}$ Somewhat paradoxically then, providing the consumer - especially the unsophisticated one - with an exhaustive contract and a comprehensive list of product attributes may lead to adverse effects for consumer empowerment. Offering too much information may be dysfunctional in that it makes the purchase decision more difficult and time-consuming to reach. It may even induce the consumer to either completely disregard the information given (leading to a random choice) or to consider it only selectively, with no guarantee that the objectively critical product attributes will be included in the consumer's subjective selection (Jacoby 1984, 435; Grundmann 2002, 286). This selectiveness of consumer attention has important policy implications. Policymakers should concentrate not on how much information is provided but on which information is accessed in practice (Jacoby 1984, 435).

The selectiveness and limits of consumer attention can be exploited by sellers (Jacoby 1984, 435; Korobkin 2003, 1233; Persson 2018, 102). Firms can use advertising to manipulate the attention of prospective buyers, making them pay attention to product attributes which they otherwise would not consider salient (Korobkin 2003, 1241). Advertising, also disguised as advice offered to the buyer by an agent of the seller at the point of sale (Engel and Stark 2015, 115-116; Stark and Choplin 2009, 662-666), might have the effect of distorting the consumer's perception of what the truly important attributes are. Consumer preferences may thus be adversely influenced, leading to an inefficient purchase decision (Ben-Shahar 2009, 16; Lissowska 2010, 60). ${ }^{12}$

10 See also the decision theory literature referenced in Korobkin 2003, supra notes 76-77 and $81-82$, at $1226-1227$.

11 See also the studies referenced in Engel and Stark 2015, supra note 27 at 113.

12 An example of such manipulation is the use of maximum speed values as the basis of the advertised download speed of the internet access services (for examples of advertised speed definitions on the Polish market see Nałęcz 2017); in practice, information about the normally available and minimum speeds is more important in making an informed decision on which internet access service to buy. Such information, however, is not exposed in advertisements. 
In any case, advertisers can only be trusted to point out the good aspects of a product (Armstrong 2008, 103). Thus, consumer policy should aim to 'provide product information which it is not in the industry's interest to provide itself' (Armstrong 2008, 142-143).

Behavioural law and economics literature provides valid arguments against the assumption that every consumer's attention can be focused on all the contract terms and on all the attributes of a product. The goal of consumer policy should be to provide the sophisticated consumer with all the information she requires to make an informed decision, ${ }^{13}$ while at the same time to draw the attention of the unsophisticated consumer to the very few, most important product attributes, presented in a truly and universally understandable manner, allowing the consumer to understand her future user experience. Bar-Gill and Ben-Shahar make a valid point when they observe that 'disclosure mandates (...) misconstrue people's objectives, thinking of consumers as guzzlers of technical information, not as users of products. They tell people stuff about matters that most people have no experience with, which require a theoretical framework to analyse' (Bar-Gill and Ben-Shahar 2013, 118). ${ }^{14}$ It is unrealistic to expect consumers to educate themselves about this framework before making a purchase decision, as they have neither the time nor the resources to do so. Ben-Shahar also points out that even a relatively simple contract is too complicated for a consumer, given existing levels of literacy (Ben-Shahar 2009, 13). ${ }^{15}$ Literacy levels are not the only argument against assuming all consumers benefit from being provided with detailed information. The EU survey of 2010 revealed very low arithmetic skills among European consumers

13 The traditional, neoclassical view is that market forces in competitive markets discipline sellers into providing efficient contract terms for all buyers (since the sophisticated consumers allegedly perform contract term control to the benefit of all consumers, including the unsophisticated ones), thus making unnecessary any regulatory tools that seek to inform unsophisticated consumers. This view is questioned in the literature. 'Businesses can afford to lose the small cadre of readers and dictate onerous terms to the nonreaders. Further, in more competitive climates, businesses may be able to identify readers and offer them more favorable terms' (Hillman 2006, 843). 'Exploiting the ignorance of the vast majority of consumers might be more lucrative for some businesses than competing for the smart consumers' (Hillman and Rachlinski 2002, 443).

14 For a similar argument see Stark and Choplin 2009, 661.

15 It is beyond the scope of this paper to present a complete overview of the literature on literacy levels. However, recent studies in various EU Member States show that cognitive ability and literacy levels are lower than previously assumed. The results of a survey presented in 2011 in Germany show that $14.5 \%$ of those aged 18 to 64 are functionally illiterate (that is, they can write or read and understand at most a single sentence). A 2011 survey in France identified 11\% of the adult population as functionally illiterate. According to a British 2002/2003 survey, 16\% of English people aged between 16 and 65 have low reading and writing skills (Grotlueschen, Riekmann and Buddeberg 2014, 56-60). 
- only $45 \%$ of respondents answered correctly to all three simple questions, requiring very basic arithmetic skills (EC 2011, section 14). ${ }^{16}$

It is not likely that all consumers can be empowered to the extent that they know and understand all their rights, all the obligations of sellers and all the attributes of the products on offer. Such empowerment only applies to the very few sophisticated consumers. The law and consumer policy should also cater to the much more numerous, unsophisticated buyers, for whom the costs of deciding based on complete information are simply too high (Engel and Stark $2015,108)$. They would benefit from 'rules that reduce complex information to information which is simple enough to be processed by [them]' (Grundmann 2002, 287). The information should be broken down into easy, modular pieces, 'perhaps to the point of using symbols instead of sentences' (Ben-Shahar and Schneider 2011, 729, 743).

\section{Empowering sophisticated consumers through the law - disclosure obligations under Article 4 (1) of Regulation 2015/2120}

\section{Introduction to disclosure obligations under Article 4 (1)}

Regulation 2015/2120 seeks to empower end-users through effective provisions enabling them to make informed choices about internet access services. ${ }^{17}$ Foremost among those provisions is Article 4 (1) of Regulation $2015 / 2120$, under which providers of internet access services shall ensure that the contract specifies at least the characteristics of the service listed in points (a) through (e). This information must also be published.

The scope of the information is considerable. Under Article 4 (1) (a), the contract must provide information on how traffic management measures applied by the provider could impact on the quality of the internet access services, on the privacy of end-users and on the protection of their personal data. Under Article 4 (1) (b), the contract must clearly and comprehensibly explain how any volume limitation, speed and other quality of service parameters may in practice have an impact on internet access services, and in particular on the use of content, applications and services. Under Article 4 (1) (c), the

16 The questions were: 1) The same flat-screen TV is on sale in both shop A and B. Which one is cheaper? 2) Thinking now about savings or deposit accounts, which of the following would be the best interest rate? $1 \%, 2 \%, 3 \%, 4 \%$; 3) A family is charged interest at $6 \%$ per year on a 50000 euro home loan. How much is the interest for the first year? $€ 300, € 3000$, $€ 5000, € 6000$ (EC 2011, supra note 12 at 7).

17 Regulation 2015/2120, recital 19. 
contract must clearly and comprehensibly explain how any services referred to in Article $3(5)^{18}$ to which the end-user subscribes might in practice have an impact on the internet access services provided to that end-user. Under Article 4 (1) (d), the contract must clearly and comprehensibly explain the minimum, normally available, maximum and advertised download and upload speed of the internet access services in the case of fixed networks, or of the estimated maximum and advertised download and upload speed of the internet access services in the case of mobile networks, and how significant deviations from the respective advertised download and upload speeds could impact the exercise of the end-users' rights laid down in Article 3 (1). Finally, under Article 4 (1) (e), the contract must clearly and comprehensibly explain the remedies available to the consumer in accordance with national law in the event of any continuous or regularly recurring discrepancy between the actual performance of the internet access service regarding speed or other quality of service parameters and the performance indicated in accordance with points (a) to (d). All the above information is included in the already long and complicated contract on the end-user's electronic communications service. ${ }^{19}$

From the point of view of the sophisticated consumer, contractually providing meaningful, realistic and accurate information on the internet access service allows it to be qualified as a search good - one the qualities of which may be assessed at the moment of sale - rather than an experience good, the qualities of which may only be assessed after purchase. ${ }^{20}$ The information will play this important role only if it is presented in a comprehensible form. Below in part III I propose an interpretation of Article 4 (1) that seeks to achieve this comprehensibility for the benefit of the sophisticated consumers.

\section{Information on the impact of traffic management measures}

Unlike the following points (b) through (e) of Article 4 (1), point (a) does not require the relevant information to be provided in a clear and comprehensible manner. One is tempted to speculate that even the European

18 These are the so-called 'specialized services', allowing optimised access to specific content, applications or services.

19 For example, the standard form contract of the Polish electronic communications provider Netia SA contains almost 9300 words, which translates into an 18 page single spaced document when formatted in a 12pt Times New Roman font (https://www.netia.pl/files/pomoc/ dokumenty_2017/regulamin_swiadczenia_uslug_przez_spolki_grupy_netia_druk_1711.pdf).

${ }^{20}$ On the role of providing meaningful information in transforming experience goods into search goods see Grundmann 2002, 285. 
lawmaker did not believe it possible to explain an issue as complicated as traffic management in a way that would be both relatively detailed and easy to understand. Studies show that people without computer science or related backgrounds have only a very basic idea of how the internet works, treating it as a 'magic black box' handling the exchange of information (Kang et al. 2015). Trying to explain in the contract even the basic technical aspects of traffic management to an otherwise sophisticated consumer without computer science education would be an exercise in futility. Such attempts are bound to create confusion rather than empowerment. For example, in order to explain how traffic management measures could impact the quality of internet access services, consumers would have to be informed if the provider distinguishes between various categories of traffic, and if so - what these categories are, how traffic is assigned to a specific category and how each category is treated under various circumstances. This information should be accompanied by an explanation of how traffic on the internet works, including, but not limited to, packet data transmission, queueing in routers, and congestion. Such information would go into technical detail beyond the grasp of anybody without a computer science education. It would also require the provider to amend the contract each time it introduced new traffic management measures, which would be extremely inefficient. Therefore, the information provided to end-users, and especially to consumers, must necessarily be less detailed, to the point of losing any objective salience. An overview of contracts used by Polish internet access service providers shows that usually they simply quote Article 3 (3) and (4) verbatim. Such a solution seems better than the extremely technical alternative.

It would be best if Regulation 2015/2120 did not require internet access service providers to provide end-users with information on traffic management. After all, under Article 3 (3) and (4), traffic management has been rather strictly regulated and it is up to the regulators to ensure that internet access service providers do not use measures contrary to the principles and rules set out in the provisions mentioned. As it is, consumers are only very broadly - and meaninglessly - informed about the issue. However, as has been indicated above, there is no better alternative.

\section{Information on the influence of volume limitations and quality of service parameters}

The contract should provide information allowing the end-user to understand the implications of the internet access service's parameters to the usage of internet services and applications (BEREC 2016, section 137). Objectively 
estimated download and upload speed, and delay requirements of various popular internet services and applications should be presented. The regulator may indicate these speed and delay values to be replicated by internet access service providers in the information presented to consumers. It is currently estimated by EU regulators that: ultra-high definition video requires an actual download speed ${ }^{21}$ of $25 \mathrm{Mb} / \mathrm{s}$; high definition video $-6 \mathrm{Mb} / \mathrm{s}$; standard definition video $2 \mathrm{Mb} / \mathrm{s}$; real-time on-line games $-2 \mathrm{Mb} / \mathrm{s}$; non-real-time on-line games $-1 \mathrm{Mb} / \mathrm{s}$; website browsing $-1 \mathrm{Mb} / \mathrm{s}$; music streaming $-0,5 \mathrm{Mb} / \mathrm{s}$; voiceover-Internet-Protocol (VoIP) conversations $-64 \mathrm{~Kb} / \mathrm{s}$. Most applications and services require a delay no higher than $150-200 \mathrm{~ms}$, while real-time on-line games require a delay no higher than $30 \mathrm{~ms}^{22}$ The explanation should be simple enough for a consumer with reasonable arithmetic skills to calculate what content she and the other members of her household would be able to use at the same time. Given the popularity of the strictly digital distribution of media such as games (Lee, Holmes and Lobe 2016), the contract should also allow the end-user to estimate how long it would take to download the files related to such media, e.g. in sizes of 5, 10, 25, 50 and 100 GB. The end-user should be instructed to make the relevant calculations based on the normally available speed of the internet access service, rather than the maximum speed. ${ }^{23}$

If the internet access service comes with volume limitations, the contract should allow the end-user to easily calculate for how long various services and applications could be used before the volume limitation is reached. This may be achieved by explaining how many minutes of watching video (ultrahigh definition, high definition, and standard definition), streaming music or playing real-time on-line games may be enjoyed under various volume limitations, e.g. $100 \mathrm{MB}, 1 \mathrm{~GB}$ etc.

\section{Information on the impact of specialised services}

The end-user should be informed if and how the activation of specialised services affects her own internet access service (BEREC 2016, section 122). For example, it should be explained that using a specialised service will reduce the maximum and normally available speeds of the internet access service, or that delay will be increased. This information must be included only in contracts which actually include both internet access and specialised services (Piątek 2017, 285).

21 Rather than a maximum speed.

22 Data based on: Ofcom 2016, 1; UKE 2014, 36-37.

${ }^{23}$ For an explanation of internet access speeds, see III.5 below. 


\section{Information on download and upload speeds}

The minimum speed is the lowest speed that the provider undertakes to deliver to the end-user (BEREC 2016, section 143; Piątek 2017, 289-290). That initial sentence notwithstanding, BEREC indicates that non-conformity of performance regarding the agreed minimum speed occurs when the actual speed is significantly, and continuously or regularly, lower than the minimum speed (BEREC 2016, section 143). Such an interpretation of the provision of Article 4 (1) (d) is unacceptable. There can be no doubt that an end-user who read the contract would understand the term 'minimum speed' in accordance with its natural, linguistic meaning. 'Minimum' means the least quantity assignable, admissible or possible. ${ }^{24}$ Allowing for the actual speed to be lower than the value described as the minimum removes all meaning from that description. One is tempted to speculate that such convoluted interpretations of otherwise clear and understandable terms are one of the forces acting against consumers reading contracts in the first place. Why read when even the simplest terms are not what they appear? Therefore, I propose a strict, linguistic interpretation of the term 'minimum speed', with only one caveat regarding the provider's liability - the provider should not be liable for delivering an actual speed lower than the minimum for reasons outside its control, for instance in cases of force majeure.

The normally available speed is the speed that an end-user could expect to receive most of the time when accessing the service (BEREC 2016, section 147; Piątek 2017, 291). This is by far the most important speed parameter from the point of view of a consumer, since it determines the ability of the internet access service to handle traffic generated by the end-user's internet services and applications in standard, everyday situations. This speed should be explained, firstly, by a numerical value, and secondly, by an indication of the time of day when it is available. Sociological literature confirms anecdotal assumptions and indicates that traffic generated by private use of the internet increases after the end of working hours in the late afternoon, peaks in the evening and decreases at night (Vilhelmson, Thulin and Elldér 2017). Thus, in consumer contracts, the normally available speed should be required to be available for most of the duration of the afternoon and of the evening, when most consumers use the internet. Any other interpretation of the provision of Article 4 (1) (d) would be contrary to the naming of the speed as 'normally available' and it would go against the purpose of Article 4, which is to provide end-users, including consumers, with meaningful information. It is certainly

${ }^{24}$ Definition from the Merriam-Webster on-line dictionary of English, https://www.merriamwebster.com/dictionary/minimum.

YeARBOOK of Antitrust and Regulatory Studies 
not enough to specify that this speed is available more than 12 hours per day (or more than $50 \%$ of the day), since that does not indicate what speed is at the disposal of the end-user during peak hours. Even more unacceptable would be defining this speed as available during most of the billing cycle, since that would allow for lower speeds for days or even weeks at a time, which would be utterly unreconcilable with the idea of a 'normally available' speed - 'transparency amounts to more than mere calculus. It must be meaningful transparency' (van Boom, 2011, 373).

The maximum speed is the one that an end-user could expect to receive at least some of the time, for example at least once a day (BEREC 2016, section 145). The moment when this speed becomes available may occur during the hours of reduced traffic, specifically at night. Thus, the maximum speed is in practice the least important from the point of view of the end-user, since its availability typically will not coincide with her internet activity. However, this speed should indeed be realistically achievable in the service purchased by the end-user in whose contract the numerical value of the speed was specified (Piątek 2017, 290). That means that it may not be assigned a numerical value equal to the theoretical maximum speed achievable by a given network technology (for example fibreoptic cable) only under artificial testing conditions, for example exclusively in laboratory testing. Informing an end-user, especially a consumer, of such a value would be misleading rather than meaningful.

The advertised speed is the one the provider uses in its commercial communications, including advertising and marketing (BEREC 2016, section 150; Piątek 2017, 293). For the information on the advertised speed to be meaningful rather than misleading, several conditions must be met. Firstly, the advertised speed should be rooted in reality. It may not be assigned an abstract numerical value. In no case should it be higher than the maximum speed actually available to at least some of the end-users in the provider's real-world network - most of all it should not be specified as equal to the theoretical maximum speed of a given network technology. Secondly, different numerical values might have to be used in direct marketing and in other forms of marketing. Direct marketing involves targeting a specific individual in order to influence her purchase decision by satisfying her individual preferences (Lipowski 2016, 103-104). Such a person should be informed of an advertised speed that is no higher than the maximum speed she would be able to utilise after signing the contract, for instance at the end-point at her disposal in the case of internet access at a fixed location. In other forms of marketing, the advertised speed should be based on the maximum speed achievable in the area where the service is offered (which might be of a national scale). 
The estimated maximum speed (in a mobile network) is the speed that should realistically be available to the end-user in the service she purchased, in various locations and under real circumstances (BEREC 2016, section 153; Piątek 2017, 294). Just like the maximum speed in a fixed network, it may not be specified as equal to the theoretical maximum speed of a given network technology. Different realistically estimated maximum speed values should be presented for the different technologies used in the provider's network (for example GPRS, EDGE, HSPA+, LTE).

It is unfortunate that Regulation 2015/2120 does not expressly require providers to inform end-users that one of the main differences between internet access in a fixed network and in a mobile network is the fact of the lack of a relatively predictable, normally available download and upload speed in the latter. For consumers to make truly informed decisions on which service to choose in a competitive market, they would have to understand this. Provider's disclosure mandates to that effect could and should be legislated by the individual Member States.

\section{Information on the remedies available to consumers}

Information on the remedies available to consumers under national law in the event of a discrepancy between the actual performance of the internet access service and its performance indicated in the contract should provide the consumer with practical, useable knowledge on what to do when her service acts up. A simple enumeration of the remedies, devoid of an explanation of how to use them, would not be sufficient, since Article 4 (1) (e) specifically calls for an explanation of the remedies. Therefore, the contract should specify whom and how to contact (for example the provider, a court, the regulator), what claims to submit (for example claims for: a price reduction, early termination of the contract, damages, a rectification of the non-conformity of performance - or any other claims enforceable under national law; BEREC 2016, section 158) and how to submit them (for example in writing or using an on-line form), how long it will take to settle the case, and whether any additional costs will be incurred by the consumer (for example the costs of proceedings). All this information should be provided in a way understandable to a person without an education in law, since the lack of understanding of the law is one of the reasons consumers often forgo the use of legal remedies (Pietraszewski 2010, 41). 


\section{Publishing information specified in Article 4 (1)}

Article 4 (1) second subparagraph requires providers of internet access services to publish all the information referred to in the first subparagraph and elaborated upon above. This obligation is an important element of consumer empowerment, since it is meant to grant consumers access to all the information necessary to make an informed decision on the purchase and use of internet access services. The information should be disclosed to the public in a way that makes all of it readily available, specifically on the provider's website and at all its points of sale. Publishing will be meaningful only when the information is properly organised and presented. An analysis of the practices of Polish providers of internet access services shows that in many cases they publish documents on unsorted lists encompassing all the standard form contracts, promotional terms and conditions, and tariffs in use by the given provider. Thus, the consumer is presented with a list of dozens of documents with no clear indication which of them relate to the service she would like to purchase. In isolated cases, the names of services used by the provider in commercial communications, such as advertising, do not match the names under which those services are described in the published information, which is bound to sow confusion among consumers (Nałęcz 2017, 32-33).

The obligation specified in the second subparagraph of Article 4 (1) of Regulation 2015/2012 will serve the empowerment of sophisticated consumers only if the manner in which the relevant information is presented is taken into consideration. All the information on every distinct variant of a service offered by a provider should be clearly gathered in the same place, be it on a website or at a physical location.

\section{Empowering unsophisticated consumers through the insights of behavioural economics - labelling internet access services}

What interests the end-user in practice is what the internet access service is really good for. Will it or will it not be good enough to serve the needs of the household? How the answer to that question translates into the technical characteristics of the service (including the numerical values of the download and upload speeds or packet delay) is not meaningful to the unsophisticated, marginal end-user - especially one who is a consumer. This assumption is 
supported by data from the Polish internet access service market. A survey conducted in 2017 showed that $72,3 \%$ of the representative sample population of Polish consumers did not know the maximum speed of their internet access service at a fixed location. ${ }^{25}$ Apparently, an overwhelming majority of Polish consumers are ignorant of the numerical values of internet access speeds. However, at the same time, they are aware of what their internet access service is good for in practice (UKE 2017, 22-24).

I propose introducing a system of clearly and prominently labelling internet access services with simple descriptions and symbols, indicating the real-world usefulness of a particular variant of the service for households with different numbers of members. By looking at the label, the consumer would be able to assess at a glance whether a given service would satisfy the needs of her household, without having to read the overcomplicated contract and educate herself on the theoretical framework needed to understand it (neither of which the consumer would most likely do at all) or having to rely on the one-sided information provided through the seller's advertising and by its salespeople (which might lead to an inefficient purchase decision, resulting from the overexposure of the practically meaningless maximum speed or estimated maximum speed of the service).

The label should be designed as a very simple and visually appealing table, using natural language and instinctively understandable symbols. Its columns would represent households with different numbers of members, with icons in the column headers showing the given number of people in a household. The table's rows would represent the ability to use internet services and applications with various requirements as to the quality of service parameters. For the sake of simplicity, there should be as few rows as possible, one indicating the ability to use only the most basic of internet content, such as sending and receiving e-mail and browsing websites, and another indicating the ability to access all content, including highest quality video. The introduction of an intermediate row would also be advisable, encompassing all internet content except for the most bandwidth intensive, highest quality video. Since real-time on-line games rely on low packet delay to a much greater extent than other internet content does ${ }^{26}$, they would require a separate row in the table. Unambiguous, commonly recognised symbols at the intersections of the columns and rows - such as green ticks and red crosses - would indicate if a given set of services and applications would realistically be available to all the members of the household, all of them accessing the internet at the same time.

25 The survey did not enquire after speeds other than the maximum.

${ }^{26}$ See section III.3 above. 
Figure 1. An example of what a label proposed in the article might look like in the case of an internet access service in a fixed network with a normally available speed of $60 \mathrm{Mb} / \mathrm{s}$ and a delay of $30 \mathrm{~ms}$

\begin{tabular}{|c|c|c|c|c|c|}
\hline \multicolumn{6}{|c|}{ Will everybody at home be able to access all types of internet content at the same time? } \\
\hline & $i$ & $\phi$ & $i$ & \|\| & $\| i$ \\
\hline All popular services and applications & $\sqrt{ }$ & $\checkmark$ & $x$ & $x$ & $x$ \\
\hline $\begin{array}{l}\text { Most popular services and applications, } \\
\text { excluding highest quality video }\end{array}$ & $\sqrt{ }$ & $\sqrt{ }$ & $\checkmark$ & $\sqrt{ }$ & $\sqrt{ }$ \\
\hline $\begin{array}{l}\text { Basic services and applications } \\
\text { (e-mail, browsing the web) }\end{array}$ & $\sqrt{ }$ & $\sqrt{ }$ & $\checkmark$ & $\sqrt{ }$ & $\checkmark$ \\
\hline Real-time on-line games & $\checkmark$ & $\checkmark$ & $\checkmark$ & $\checkmark$ & $\checkmark$ \\
\hline
\end{tabular}

The functionality of the service visualised on the label should be based on all the relevant quality of service parameters realistically, reliably and predictably available in the provider's network. For the purpose of accessing internet content other than real-time on-line games, foremost among the relevant parameters is the normally available download and upload speed. Basing the information on the label on the maximum speed value - which, as was mentioned above, is also usually presented in the provider's marketing as the advertised speed - would defeat the whole purpose of meaningfully empowering unsophisticated consumers in making decisions on choosing their internet access services. A quality of service parameter that is met possibly as infrequently as once daily - which may be true of the maximum speed - is no proper basis for describing the utility of an internet access service to a consumer seeking to satisfy the real-world needs of herself and her household. Normally available packet delay should also be taken into account.

In the case of internet access services in mobile networks, the service's technical characteristics determine that a normally available speed may not be specified. This should be reflected in the label of such services - the label should indicate that it may not be determined whether the internet access service will 
be able to reliably serve the needs of all the members of the household. ${ }^{27}$ This could be done by using a question mark symbol in the table instead of a tick or cross symbol. Such a solution would benefit especially a consumer who is considering a choice between two internet access services - one provided in a fixed network, and the other in a mobile network. By comparing the labels of the two services, the consumer would instantly perceive the difference between their reliable, real-world ability to allow access to internet content. This would be possible even for a consumer without the theoretical framework needed to read and understand a standard form contract involving internet access services.

The label should be prominently displayed in any contract that includes an internet access service, and in all the documents published under the second subparagraph of Article 4 (1) of Regulation 2015/2120. The design and layout of the label should be uniform for all internet access services offered by all providers, in order to facilitate the comparison of various services by consumers.

The use of the labels proposed above may be recommended to the providers of internet access services by the soft law of national regulatory authorities. An obligation to label internet access services would have to be legislated either at the EU level, as an amendment to Article 4 of Regulation 2015/2120, or at the level of the individual Member States.

\section{Conclusions}

European policy seeks to empower consumers through choice, information and awareness of consumer rights and means of redress. The EU also integrates consumer interests into key sectorial policies, including the electronic communications policy. Regulation 2015/2120 aims to empower end-users, including consumers, through provisions enabling them to make informed choices about internet access services. Consequently, Article 4 (1) of Regulation 2015/2120 requires the providers of those services to disclose relevant information to end-users in the contract. A review of the behavioural law and economics literature provides arguments against blind faith in such

27 Traffic in mobile networks may be unpredictable. Traffic hotspots occur when a cell in a mobile network experiences significant traffic, impacting the quality of service. Hotspots occur randomly across the network. A recent study showed that download hotspots offer average download speeds ranging between $0,9 \mathrm{Mb} / \mathrm{s}$ and $19,1 \mathrm{Mb} / \mathrm{s}$ (Nika et al. 2016). While many applications and services would be useable at the high end of the range, few would be at the low end. 
disclosure mandates. Behavioural economics research supports the division of consumers into an unsophisticated majority and a sophisticated minority. Unsophisticated consumers rely on superficial information, such as that gleaned from advertising, when determining the high-level characteristics of the goods on offer and making purchase decisions, which often turn out to be inefficient. They lack the theoretical framework to read and understand contracts. Sophisticated consumers rely on detailed information, including data disclosed in the contract - however only if it is properly presented.

In the case of internet access services, consumer policy should seek to transform them from experience goods into search goods. This goal will be achieved only if certain conditions are met. In the article I proposed a comprehensive interpretation of Article 4 (1) of Regulation 2015/2120 that takes into account the need to describe the internet access service as an actual product, used in the real world by real people. Such an approach should encourage the sophisticated consumers to read contracts, leading to their true empowerment. I also proposed the labelling of internet access services for the benefit of the unsophisticated consumers, who are 'unempowerable' when the means of empowerment are traditional disclosure mandates, based on providing the consumer with more information than she can process, crammed into a contract so long and complex no average person can be realistically expected to read it, let alone understand all of it. The labels would serve to provide the unsophisticated consumers with information necessary to make a reasonably informed decision when choosing an internet access service, instead of having to rely on the cherry-picked characteristics of the service stressed in advertising. The use of the labels may be either recommended by the soft law of national regulatory authorities or made obligatory under new legislation.

\section{Literature}

Armstrong, M. (2008). Interactions between Competition and Consumer Policy. Competition Policy International 4 (1): 97-147. Retrieved from: https://pdfs.semanticscholar.org/4f13 /1929e36042e637e22765f9674edbc6886e98.pdf.

Ayres, I., and A. Schwartz. (2014). The No-Reading Problem in Consumer Contract Law. Stanford Law Review 66 (3): 545-610. Retrieved from: http://www.stanfordlawreview. org/wp-content/uploads/sites/3/2014/03/66_Stan_L_Rev_545_AyresSchwartz.pdf.

Bakos, Y., F. Marotta-Wurgler, and D.R. Trossen. (2013). Does Anyone Read the Fine Print? Consumer Attention to Standard Form Contracts. New York University Law and Economics Working Papers 195. Retrieved from: http://lsr.nellco.org/nyu_lewp/195.

Bar-Gill, O., and O. Ben-Shahar. (2013). Regulatory Techniques in Consumer Protection: A Critique of European Consumer Contract Law. Common Market Law Review 50 (1/2): 109-126. doi: 10.2139/ssrn.2061148. 
Becher, S.I. (2007). Behavioral Science and Consumer Standard Form Contracts. Louisiana Law Review 68 (1): 117-179. Retrieved from: https://digitalcommons.law.lsu.edu/cgi/ viewcontent.cgi? article $=6222 \&$ context $=$ lalrev.

Becher, S.I., and E. Unger-Aviram. (2010). The Law of Standard Form Contracts: Misguided Intuitions and Suggestions for Reconstruction. DePaul Business and Commercial Law Journal 8 (3): 199-227. Retrieved from: http://via.library.depaul.edu/bclj/vol8/iss3/2.

Ben-Shahar, O. (2009). The Myth of the 'Opportunity to Read' in Contract Law. European Review of Contract Law 5 (1): 1-28. doi: 10.1515/ERCL.2009.1.

Ben-Shahar, O., and C.E. Schneider. (2011). The Failure of Mandated Disclosure. University of Pennsylvania Law Review 159 (3): 647-749. Retrieved from: https://www. law.upenn.edu/journals/lawreview/articles/volume159/issue3/BenShaharSchneider159U. Pa.L.Rev.647(2011).pdf.

BEREC. (2016). BEREC Guidelines on the Implementation by National Regulators of European Net Neutrality Rules. BoR (16) 127. Riga: Body of European Regulators for Electronic Communications. Retrieved from: berec.europa.eu/eng/document_register/ subject_matter/berec/download/0/6160-berec-guidelines-on-the-implementation-b_0. pdf.

Eigen, Z.J. (2012). Experimental Evidence of the Relationship between Reading the Fine Print and Performance of Form-Contract Terms. Journal of Institutional and Theoretical Economics 168 (1): 124-141. doi: 10.1628/093245612799440050.

Engel, M., and J. Stark. (2015). Buttons, Boxes, Ticks and Trust. On the Narrow Limits of Consumer Choice. In: K. Mathis (ed) European Perspectives on Behavioural Law and Economics. Cham: Springer. doi: 10.1007/978-3-319-11635-8.

Epstein, R.A. (2008). The Neoclassical Economics of Consumer Contracts. Minnesota Law Review 92 (3): 803-835. Retrieved from: https://chicagounbound.uchicago.edu/cgi/ viewcontent.cgi? article $=2218 \&$ context $=$ journal_articles.

EC. 2011. Consumer Empowerment in the EU. Commission Staff Working Paper. Brussels: European Commission. https:/ec.europa.eu/info/sites/info/files/consumer_ empowerment_eu_2011_en.pdf.

Faure, M.G., and H.A. Luth. (2011). "Behavioural Economics in Unfair Contract Terms. Cautions and Considerations." Journal of Consumer Policy 34 (3): 337-358. doi: 10.1007/ s10603-011-9162-9.

Geistfeld, L.V., G.B. Sproles, and S.B. Badenhop. (1977). The Concept and Measurement of a Hierarchy of Product Characteristics. Advances in Consumer Research 4: 302-307. Retrieved from: http://acrwebsite.org/volumes/9380/volumes/v04/NA-04.

Grotlueschen, A., W. Riekmann and K. Buddeberg. (2014). Functional Illiteracy in Germany. In: H. Hinzen and J.H. Knoll (eds), Lifelong Learning and Governance. From Programming to Action - Selected Experiences from Asia and Europe. Vientiane: DVV International. Retrieved from: http://pumr.pascalobservatory.org/sites/default/ files/qelll_2014244.pdf.

Grundmann, S. (2002). Information, Party Autonomy and Economic Agents in European Contract Law. Common Market Law Review 39 (2): 269-293. Retrieved from: https:// edoc.hu-berlin.de/bitstream/handle/18452/10034/26qyIKnaeOlfg.pdf?sequence $=1$.

Hillman, R.A., and J.J. Rachlinski. (2002). Standard Form Contracting in the Electronic Age. New York University Law Review 77 (2): 429-495. Retrieved from: http://www. nyulawreview.org/sites/default/files/pdf/NYULawReview-77-2-Hillman-Rachlinski.pdf. 
Jacoby, J. (1984). Perspectives on Information Overload. Journal of Consumer Research 10 (4): 432-435. Retrieved from: http://www.jstor.org/stable/2488912.

Kang, R., L. Dabbish, N. Fruchter, and S. Kiesler. (2015). My Data Just Goes Everywhere: User Mental Models of the Internet and Implications for Privacy and Security. In: Proceedings of the Eleventh Symposium on Usable Privacy and Security, Ottawa, Canada, July 22-24, 2015. Berkeley: USENIX. Retrieved from: https://www.usenix.org/sites/ default/files/soups15_full_proceedings.pdf.

Korobkin, R. (2003). Bounded Rationality, Standard Form Contracts, and Unconscionability. The University of Chicago Law Review 70 (4): 1203-1295. Retrieved from: https:// chicagounbound.uchicago.edu/uclrev/vol70/iss4/2.

Lee, J.H., D. Holmes and B. Lobe. (2016). Media format matters: User's perceptions of physical versus digital games. Proceedings of the Association for Information Science and Technology 53 (1): 1-10. doi: 10.1002/pra2.2016.14505301031.

Lipowski, M. (2016). „Kanał komunikacji a kanał dystrybucji - zanikanie różnic i ich konsekwencje”. Studia Ekonomiczne. Zeszyty Naukowe Uniwersytetu Ekonomicznego w Katowicach (254), 99-107. http://yadda.icm.edu.pl/yadda/element/bwmeta1.element. cejsh-882bab4f-8958-4da4-b614-8ff5f8675050.

Lissowska, M. (2010). Polityka konsumencka - podstawy teoretyczne, cele i narzędzia. Gospodarka Narodowa (10): 57-77. Retrieved from: http://gospodarkanarodowa.sgh. waw.pl/p/gospodarka_narodowa_2010_10_03.pdf.

Nałęcz, A. (2017). Analiza dotycząca środków przejrzystości określonych w art. 4 ust. 1 rozporządzenia 2015/2120 na przykładzie rozwiązań przyjętych na polskim rynku telekomunikacyjnym. CARS. Retrieved from: https://www.cars.wz.uw.edu.pl/tresc/ badania/23/Ekspertyza_UKE_1_Andrzej_Nalecz_CARS.pdf.

Nika, A., A. Ismail, B.Y. Zhao, S. Gaito, G.P. Rossi, and H. Zheng. (2016). Understanding and Predicting Data Hotspots in Cellular Networks. Mobile Networks and Applications 21 (3): 402-413. doi: 10.1007/s11036-015-0648-6.

Obar, J.A., and A. Oeldorf-Hirsch. (2016). The Biggest Lie on the Internet: Ignoring the Privacy Policies and Terms of Service Policies of Social Networking Services. Paper presented at TPRC 44: The 44th Research Conference on Communication, Information and Internet Policy 2016. doi: 10.2139/ssrn.2757465.

Ofcom. (2016). UK Home Broadband Performance. A consumer summary of fixed-line broadband performance. London: Ofcom. Retrieved from: https://www.ofcom.org. uk/_data/assets/pdf_file/0018/100755/UK-home-broadband-performance,-November2016-Consumer-guide.pdf.

Persson, P. (2018). Attention manipulation and information overload. Behavioural Public Policy 2 (1): 78-106. doi: 10.1017/bpp.2017.10.

Piątek, S. (2017). Rozporzadzenie UE Nr 2015/2120 w zakresie dostępu do otwartego internetu. Warszawa: Wydawnictwo C.H. Beck.

Pietraszewski, M. (2010). Wybrane problemy na tle alternatywnych metod rozstrzygania sporów z udziałem konsumentów." Kwartalnik ADR (4): 41-61. Retrieved from: http:// arbitraz.laszczuk.pl/_adr/150/Wybrane_problemy_na_tle_alternatywnych_metod_ rozstrzygania_sporow_z_udzialem_konsumentow.pdf.

Schebesta, H., and K.P. Purnhagen. (2016). The behaviour of the average consumer: A little less normativity and a little more reality in CJEU's case law? Reflections on Teekanne. Wageningen Working Paper, Law and Governance. Wageningen University 
\& Research centre, 2016/03. Retrieved from: http:/library.wur.nl/WebQuery/wurpubs/ fulltext/393406.

Stark, D.P., and J.M. Choplin. (2009). A License to Deceive: Enforcing Contractual Myths Despite Consumer Psychological Realities. NYU Journal of Law \& Business 5 (2): 617-744. Retrieved from: https://docs.wixstatic.com/ugd/716e9c_82e3e227fadb44d 984c20cf15f65aec6.pdf.

UKE. (2014). Raport $z$ prac realizowanych $w$ ramach memorandum $w$ sprawie wspótpracy na rzecz podnoszenia jakości ustug na rynku telekomunikacyjnym. Warszawa: Urząd Komunikacji Elektronicznej. Retrieved from: https://archiwum.uke.gov.pl/files/?id_ plik $=15142$.

UKE. (2017). Badanie opinii publicznej w zakresie funkcjonowania rynku ustug telekomunikacyjnych oraz preferencji konsumentów. Warszawa-Gdańsk: Urząd Komunikacji Elektronicznej. Retrieved from: http://www.telepolis.pl/grafika/newsy/201801/raport_analityczny_klienci_indywidualni.pdf.

Van Boom, W.H. (2011). Price Intransparency, Consumer Decision Making and European Consumer Law. Journal of Consumer Policy 34 (3): 359-376. doi: 10.1007/s10603-0119163-8.

Vilhelmson, B., E. Thulin, and E. Elldér. (2017). Where does time spent on the Internet come from? Tracing the influence of information and communications technology use on daily activities. Information, Communication \& Society 20 (2): 250-263. doi: 10.1080/1369118X.2016.1164741. 